\title{
An evolutionary model for ethics in investment
}

Received (in revised form): 24th May, 2000

\section{Dr Craig Mackenzie}

is Director of Governance and Responsible Investment at Friends Ivory \& Sime. He has a PhD in business ethics. He is a Board Director of the UK Social Investment Forum and Council Member of the Institute of Social and Ethical Accountability (ISEA), a member of the Environment and Society Committee, Association of Chartered Certified Accountants (ACCA), and a judge for the ACCA/ISEA Social Reporting Awards.

\begin{abstract}
In the past, UK pension funds have resisted the suggestion that they should take account of ethical and environmental issues in investment. One reason for this is that the model proposed for doing so involved the exclusion, on ethical grounds, of a significant proportion of the investment universe. This was widely considered to be legally unsafe. Following the introduction of a new Pensions Act disclosure regulation on this subject, attitudes have changed, largely because new models have emerged for taking account of ethical issues in investment. This paper describes the most popular of these models and explains the rationale for their widespread adoption.
\end{abstract}

Keywords: ethics; socially responsible investment; engagement; risk; reputation; brand; efficient markets

\section{Introduction}

A new model is emerging for taking account of social, environmental and ethical issues in investment. Traditional ethical investment takes an uncompromising approach to ethics, often putting ethical considerations ahead of financial performance. This unorthodox investment approach often raises difficulties for pension fund trustees. The new 'evolutionary' model starts with orthodox investment management and asks how it can, incrementally, take greater account of social, environmental and ethical issues in the course of financial analysis and

Dr. Craig Mackenzie (Ethics Unit, Friends Ivory \& Sime, 15 Old Bailey, London, EC4M 7EF.

Tel: +44 (0)20 7506 1100; e-mail:

Craig.Mackenzie@friendsis .com)

\section{corporate governance.}

In 1999 the government introduced a new requirement for occupational pension funds to state in their investment policies the extent to which they take account of social, environmental and ethical issues in investment. This had to be implemented by July 2000. Currently few pension funds have specific policies to take account of these issues. However, there is likely to be escalating demand from pension fund members that pension funds move forward on these issues.

Survey evidence indicates that 77 per cent of the public would like their pension fund to adopt an ethical policy, if this can be done without harming financial return (EIRIS/NOP Solutions, London, June 1999).

How will the pensions industry respond? While many pension funds may try to avoid the problem by adopting a policy of not taking account of social, environmental or ethical issues in investment, the early signs are that many leading pension funds will make some kind of positive commitment in this area. The BT, Sainsbury's, Friends Provident 
and USS pension schemes have adopted positive initiatives. None of these funds has adopted the traditional ethical investment model, but instead have sought to develop an 'evolutionary' approach to their existing investment approach. This could have far-reaching implications for pension fund investment. Indeed within a year or two we might easily see over $\mathcal{E}_{100 \mathrm{bn}}$ of investment taking the evolutionary approach to these issues.

\section{The traditional ethical investment model}

The traditional ethical investment model is based on the idea that if a company is doing something ethically questionable, you should not invest in it. In practice, traditional ethical funds exclude from the portfolio companies that fail to meet various detailed ethical or environmental criteria. A typical ethical fund might exclude half the companies in the FTSE All Share Index from its portfolio on ethical grounds. This is, to say the least, an unorthodox approach to investment for pension funds. It can lead to a significant bias towards smaller companies and tracking errors in excess of 5 per cent. Nevertheless, many ethical funds have delivered perfectly creditable financial performance over the long term, and a number of defined contribution pension schemes now offer an ethical fund as one of the fund options available in the scheme. Similarly, a number of AVC schemes make available such fund options. It is usually considered to be harder to apply this model to defined benefit schemes because there is some doubt about whether large-scale exclusion of stocks on ethical grounds is compatible with trust law. Having said that, a number of defined benefit schemes have felt comfortable investing a small percentage of their overall fund in an ethically screened portfolio.

\section{The evolutionary model}

One of the peculiar things about the debate about the new government requirement is that the discussion seems to focus around the question of whether or not trustees should take account of social, environmental issues in investment. This is not the right question. The simple fact is that the vast majority of ordinary, completely orthodox, active pension fund managers already do take account of social, environmental and ethical considerations in investment. For example, a few years ago, when Perrier announced that its bottled water was contaminated with benzene, the company's share price fell by 35 per cent. Why did the share price fall? It fell because fund managers believed that this environmental issue might hurt Perrier's future earnings. They were right - Perrier subsequently estimated that the disaster cost $\$ 260 \mathrm{~m}$, for recall of bottles and for consequential advertising expenditure. $^{1}$

There are many other examples where social, ethical and environmental costs have an impact on earnings:

- Risks to business strategy from public rejection of key products. The rejection of genetically modified foods by the European public has weakened earnings forecasts of life sciences companies and share prices.

- Risks of environmental clean-up costs. Exxon's clean-up costs following the Valdez oil spill have been estimated at $\$ 11 \mathrm{bn} ;^{2}$ this is the most well known of many thousands of instances of environmental remediation costs faced by business, 
that are frequently mentioned in the report and accounts (particularly for US companies), and taken into account by analysts.

- Risks of legal costs and damages arising from employee law suits relating to health and safety, or sexual or racial discrimination. These costs affect earnings and are taken into account.

- Risks of costs associated with mis-selling. Current estimates for the life insurance industry are estimated at E11bn.

Social and environmental impacts do not just provide downside risks. There are also substantial opportunities.

- There are considerable opportunities arising from new products required to meet the Kyoto targets for greenhouse gas reductions: renewable energy, low emission vehicles, etc. On Shell's projections, renewable energy could be the dominant energy supply in 50 years' time. A huge amount of shareholder value is going to be created in this transition. Renewable energy companies may well be among the most spectacular growth stocks of the future. Companies like Ballard Power, which makes fuel cells, have seen their share price rise from $\$ 10$ to $\$ 200$ in the last four years, or Vestas, a wind power company whose share price has risen by around 500 per cent in three years (Datastream).

Other examples of upside benefits arising from social, environmental and ethical issues include:

- Reduced costs faced by companies who develop so-called 'ecoefficiency' measures to increase energy efficiency and materials productivity, and reduce waste.
- Premium pricing opportunities for products with perceived environmental superiority (organic food is a good example).

- A reputation for social responsibility enables companies to attract and retain the best people, cutting recruitment costs, and to attract the best suppliers and business partners.

There is a substantial body of evidence that social, environmental and ethical issues can affect the earnings of companies. This is not terribly controversial, indeed a past chairman of the NAPF has recently made this point in an article on this subject. It is also not controversial to suggest that when the linkage to earnings is well understood, analysts and fund managers do take these issues into account.

\section{Inefficient markets?}

The question is therefore not whether trustees should take account of social, environmental and ethical issues in investment. Their active fund managers already do so. The question is, are these issues being taken into account to the optimal extent?

Investors cannot value what they cannot see. And the fact is that on many social, environmental and ethical issues, there is precious little to see relating to the contribution of these issues to earnings (though there are exceptions; see case study of Baxter International).

Take the example of reputation or brand risk. According to brand marketing agencies like Interbrand, the brand assets of highly branded clothing and sporting goods companies often account for 40 per cent or more of their total assets. Their brands are frequently worth billions of pounds. ${ }^{3} \mathrm{~A}$ number of these companies have been publicly criticised for the use of child 
labour by their suppliers in the third world. Allegations of this kind can damage the brand, destroying large amounts of shareholder value. However, at present there is little agreement how companies should report on the value of intangible assets, so investors do not see the brand value being destroyed. Investors may therefore be failing to take proper account of reputational and brand risks arising from social or ethical issues such as child labour. We believe that social, environmental and ethical considerations do have a role to play in the creation of - and destruction of - shareholder value, but that all too often their role is not visible to investors.

\section{REO}

If there is any merit in the hypothesis that the market does not fully account for the role of social, environmental and ethical risks and opportunities in creating value, how can the fund management community 'evolve' to deal with it? Friends Ivory \& Sime's view is embodied in a product we developed in early 1999, called $\mathrm{REO}^{\mathrm{TM}}$ — the Responsible Engagement Overlay. On the hypothesis that the market's understanding of social, environmental and ethical issues may be incomplete, we are engaged in a programme of work to understand the relationship between social, environmental and ethical issues and business success. By discussing these issues with companies, trade associations and other experts we aim to build a detailed knowledge, for example, of best practice management of environmental, social responsibility and business ethics issues, and of the relationship between good management and business performance.

We use this knowledge as the basis for a focused programme of engagement with the companies in which we invest, to support and encourage them in their efforts to adopt best practice on these issues. We make a special effort to encourage companies to establish up the kind of high-quality management and information systems and reporting frameworks that will provide us with better information about the relationships between social, environmental and ethical impacts and shareholder value.

In an important sense REO is an extension of the traditional corporate governance agenda. We seek to address a new generation of corporate governance issues. Actually, the traditional corporate governance agenda is itself moving in this direction. The recent Turnbull Committee's addition to the Combined Code of the Committee on Corporate Governance now requires companies establish systems to identify, evaluate and manage their risks. Not just their narrowly financial risks, but all of their risks. It is particularly interesting in this context that Turnbull specifically recommends the need for risk management systems to identify non-conventional risks such as the risks relating to 'legal, health, safety, environmental, reputation and business probity issues'. ${ }^{4}$ In order to comply with Turnbull, companies will need to become rather better at identifying the kind of social, environmental and ethical risks mentioned.

While our REO ${ }^{\mathrm{TM}}$ activity has a clear financial motivation, we believe that better management of social, environmental and ethical issues will frequently provide significant benefits to society. As investors we prefer to have no surprises from the companies in which we invest. Unfortunately, unpleasant surprises for shareholders relating to social, environmental and ethical issues tend to be even more unpleasant for other stakeholders - 
industrial accidents, oil spills and fraud are good examples. Our efforts to encourage companies to avoid giving shareholders these nasty 'surprises' will therefore benefit other stakeholders as well.

\section{USS}

FIS is not alone in responding to the new pensions regulation by adopting an engagement programme. Last November, the Universities Superannuation Scheme Ltd (USS) announced an important policy shift in this direction. USS manages assets of almost $\mathcal{E}^{20}$ billion on behalf of 153,000 members in the higher education profession. ${ }^{5}$

Announcing the new policy, the USS chairman Professor Sir Graeme Davies said 'Today no properly run public company - or fund manager — should be unaware of the importance of public opinion and ethical issues. They ignore the subject at their peril. The USS, he added, supported a policy of 'more active engagement with companies" ${ }^{6}$ that would involve making requests for corporate policy changes and monitoring the results.

The USS policy says that 'increasingly, a company's reputation is a crucial asset and that reputation, of course, includes the public's perception of its ethical and environmental stance and its responsibilities to society in the general conduct of its affairs'. In implementing the policy, USS will seek to identify those companies in which the fund is invested that are following policies that do not meet best practice on social, environmental or ethical issues and may have an adverse financial impact on the value or the return on that investment. It will then make representations to such companies to seek a corporate policy change, and will monitor the results of that policy. In order to give effect to this policy, the USS is appointing additional specialist staff.

\section{Benefits for trustees}

The evolutionary model embodied in the REO and USS approaches has considerable advantages for trustees. It enables them to state a positive policy in their Statement of Investment Principles, but does not require the unorthodox investment approach associated with traditional ethical investment. For REO and, it seems, the USS model, the principal activities are information gathering and engagement with companies after the decision has been taken to invest. These approaches do not apply ethical screening criteria to the stock selection process. They therefore side-step the ongoing debates that hamper uptake of the traditional ethical investment model about whether ethical screening is compatible with trust law.

That is not to say that this approach is easy for fund managers to implement.

For a start-doing the kind of high-level work with companies that is involved in REO is very labour intensive and requires a high level of knowledge and expertise. If, as we have, you are going to have an hour-long meeting with the CEO of a major clothing company about the labour standards of its third world suppliers, you need to be very well informed indeed. Friends Ivory \& Sime has had to make a substantial investment in new staff to operate its REO programme, and it expects to expand further during this year.

\section{The consequences for investment}

Both Friends Ivory \& Sime's model and the USS model seek to address social, environmental and ethical risks by seeking to use their influence in order to encourage good governance of these 
issues. In the terms of the new Pensions Act regulation, this is a policy relating to the 'retention' of investments, as opposed to the 'selection' and 'realisation' of investment. Obviously, if there is merit in the hypothesis that the financial markets demonstrate either analytic or informational inefficiencies in regard to these issues, then operating on a governance level is only part of the solution. It would also be legitimate to explore how the investment process itself should be improved with regard to social, environmental and ethical issues. There are clearly evolutionary possibilities in this area. We have recently seen an announcement by one leading fund manager that it intends to explore these possibilities.

\section{Conclusion}

I have argued that in the light of the new disclosure regulation, the question trustees need to ask is not 'whether' to take account of ethical issues in investment, but how to do so in a systematic and comprehensive way in order more fully to serve the financial interests of their beneficiaries. I have argued that social, ethical and environmental issues can materially affect the creation of shareholder value, and that there are good reasons to believe that the financial markets are not currently taking these issues fully into account. Therefore I propose that pension funds should take an evolutionary approach to these issues in their investment and corporate governance processes. This approach should be based on developing a greater understanding of the relationship between social, environmental and ethical issues and the creation of value for shareholders.

\section{References}

1 Knight, R. and Petty, D. (1995), 'The Impact of Catastrophes on Shareholder Value', Templeton College, Oxford.

2 Ibid.

3 Interbrand (1999), 'World's Most Valuable Brands Survey', Interbrand, New York.

4 Institute of Chartered Accountants in England and Wales (1999), 'Internal Control: Guidance for Directors on the Combined Code', ICAEW.

5 USS press release, December 1999.

6 Ibid. 